\title{
Isolation of multidrug resistant bacterial pathogens and screening against Coleus amboinicus L. extracts
}

\author{
K.P. Shamna* and Muhammad Musthafa Poyil \\ Department of Basic Medical Sciences, College of Medicine, Prince Sattam Bin Abdulaziz University, Al-Kharj, 11942, Saudi Arabia \\ *Deseeya Ayurvedic Pharmaceuticals Ltd., Calicut, Kerala-673 574, India
}

\section{Article Info}

Article history

Received 1 November 2021

Revised 17 December 2021

Accepted 19 December 2021

Published Online 30 December 2021

\section{Keywords}

Antibacterial activity

Antioxidant activity

Coleus amboinicus L.

Minimum inhibitory concentration

Multidrug resistant bacteria

\begin{abstract}
World health organisation (WHO) has declared antimicrobial resistance as a global crisis. Antimicrobial resistance is an emerging issue following the COVID-19. The development of novel antibiotics has become necessary for the treatment of MDR infections. Plants serve as a potential source for developing novel drugs, and herbal-based drugs are often safe. Therefore, the present study focuses on evaluating the antiMDR bacterial activity of Coleus amboinicus L. against multidrug-resistant Escherichia coli and Staphylococcus aureus. The clinical pathogens were collected and an antibiotic susceptibility test was performed using standard antibiotics to evaluate the resistant pattern of the pathogens. Bioactive compounds of the C. amboinicus leaves were extracted using methanol as solvent. DPPH radical scavenging activity and ferric reducing antioxidant power assay were performed. The antibacterial activity and minimum inhibitory concentration (MIC) of the leaf extract against isolated MDR pathogens were investigated. Crude plant extract showed better antioxidant values, $69.31 \pm 0.69 \%$ of DPPH scavenging and $78.35 \pm$ $0.32 \%$ of reducing power was observed on $1000 \mu \mathrm{g}$ of extract. $500 \mathrm{mg} / \mathrm{ml}$ and $1000 \mathrm{mg} / \mathrm{ml}$ showed higher zones against both the test organisms. MIC of $E$. coli and $S$. aureus was found to be $15.6 \mathrm{mg}$ and $7.8 \mathrm{mg}$. From the analysis, bioactive compounds from C. amboinicus showed evident antibacterial activity against MDR pathogens and, therefore can be used for the development of antimicrobial drugs for the treatment of MDR infections.
\end{abstract}

\section{Introduction}

Antimicrobial resistance refers to a microorganism's capacity to withstand the effects of antibiotics. Resistant microbes are more difficult to treat, necessitating the use of alternative medications or higher antimicrobial doses. Resistance develops by one of three mechanisms: inherent resistance in some bacteria, genetic mutation, or the acquisition of resistance from another species. Antibiotic resistance is not completely understood worldwide, although it is more prevalent in poorer nations with weakened healthcare systems (Elbossaty, 2017).

Superbugs are strains of bacteria that have changed (or mutated) and developed resistance after coming into contact with fourth-generation antibiotics. Methicillin-resistant Staphylococcus aureus (MRSA) is probably the best-known superbug that was first observed in 1960 . Infection with a superbug might cause no symptoms in some persons. Healthy people can infect vulnerable people without even realising it, if they carry germs without showing symptoms. When symptoms of superbug infections do appear, they differ greatly depending on which organism is attacking. Even young and healthy people can contract a superbug infection. If, the person's immune system has been compromised by a chronic disease or cancer treatment, they

Corresponding author: Mr. Muhammad Musthafa Poyil

Department of Basic Medical Sciences, College of Medicine, Prince Sattam Bin Abdulaziz University, Al-Kharj, 11942, Saudi Arabia

E-mail: pmusthu@gmail.com

Tel.: +96-6565634412

Copyright (C) 2021 Ukaaz Publications. All rights reserved.

Email: ukaaz@yahoo.com; Website: www.ukaazpublications.com will be more susceptible to infection (Read, 2020; Samanjit Kaur and Sneha Hariharan, 2020).

Multidrug resistant (MDR which show resistance against three or more antibiotics) strains of bacterial pathogens is the major challenge the scienticfic world face in this century (Vidya Seshadri, 2021) and they raise medical expenses, lengthens hospital stays, and raises fatality rates. They have begun to wreak havoc on human health in recent years, taking longer to recover and increasing medical expenditures and death. Antimicrobial resistance is expected to kill 10 million people worldwide per year by 2050 . Drug-resistant infections claim the lives of at least 700,000 individuals each year. According to the Centres for Disease Control and Prevention (CDC) 2019 reports, more than 2.8 million drug resistant illnesses occur in the United States each year, with more than 35,000 of those being fatal (Wieczorek and Osek, 2011).

The vast majority of E. coli strains are harmless, and they are an important part of a healthy human digestive system. On the other hand, some of the E. coli strains can cause diseases like diarrhoea or illness outside of the intestine. Diarrhoea-causing E. coli strains can be spread through contaminated water or food, as well as contact with animals or people. There are little research on the characterisation of E. coli strains that cause bacteremia. Multidrug resistance in E. coli is also becoming a global problem, focusing on E. coli sequence type (ST) 131, which is increasingly being reported in UTIs (Elbehiry et al., 2021).

MRSA (Methicillin-resistant Staphylococcus aureus) is a versatile infection that may cause many human disorders. According to data 
from the National Nosocomial Infections Surveillance System, the frequency of nosocomial MRSA infections is gradually growing in the United States. These infections account for more than $60 \%$ of critical care unit hospitalisations. Several antimicrobial medicines, including second and third-line medications, have acquired resistance in S. aureus. It is also a common cause of food poisoning over the world. While $S$. aureus colonisation does not damage the host, it is a risk factor for developing later symptomatic infections (Panjla et al., 2019).

In the face of rising resistance to older antimicrobials and increasingly difficult bacterial infection management due to the increased incidence of multidrug-resistant (MDR) pathogens, the need for innovative antimicrobials has recently been stronger. There is a constant demand for new antibacterial drugs year after year. There is an increase in mortality, particularly for illnesses with few treatment options, such as gram-negative bacteria, which the World Health Organization has designated as "priority pathogens" and a worldwide hazard. As a result, we require innovative antibiotics to treat infections and lower the fatality rate (Rolain et al., 2016).

To tackle the issue raised by the MDR strains of bacterial pathogens, unfortunately, there are no new antibiotics with potential activities and thus, the scientists turned to natural bioactive compounds including the secondary metabolites produced in plants in an effort to extract them and to use them in various medical application, provided with the supportive informations handed over through generations (Saravanakumari et al., 2020; Gayathiri et al., 2020). Herbal drugs are promising for creating effective and novel pharmaceuticals because plants are a rich source of novel phytocompounds. India is projected to have around 47,500 plant species, accounting for more than $11.4 \%$ of the world's total plant species. Approximately, $28 \%$ of the plants found in India are indigenous to the country. These medicinal herbs have various biological activities, including antibacterial, antidiabetic, antimicrobial, antiulcer, analgesic, and antiamnesic capabilities, among others. Medicinal herbs are commonly utilised and thought to be safe and less expensive than chemically manufactured medications (Umamaheswari et al., 2021).

C. amboinicus, also known as Plectranthus amboinicus in the family Lamiaceae is a semi-succulent perennial plant with a spicy oreganolike flavour and odour. It is utilised as a spice, as well as a decorative and medicinal plant. C. amboinicus can reach a height of $1 \mathrm{~m}(3.3 \mathrm{ft})$. The stem is fleshy, measuring $30-90 \mathrm{~cm}$ (12-35 in), and is coated with either long inflexible hairs (hispidly villous) or soft, short, and upright hairs (tomentose). The stems of old trees are smooth (glabrescent). This plant has been used in ancient traditional system for treatment of various ailments. As there were several studies on antibacterial potential of $C$. amboinicus, no reports available on evaluating the anti-MDR bacterial activity. Therefore, the present study focuses on evaluating the anti-MDR bacterial activity of $C$. amboinicus against MDR Escherichia coli and Staphylococcus aureus. DPPH radical scavenging activity and ferric reducing antioxidant power assay of the extracts were performed.

\section{Materials and Methods}

\subsection{Isolation and identification of pathogens}

Clinical isolates of pathogenic bacteriawhich were isolated from the in-patients of a tertiary hospital in Erode, Tamil Nadu were cultured on nutrient media (Himedia). The pathogens were identified by the selective media growth on eosin methylene blue (EMB) agar and mannitol salt agar (MSA). The green metallic sheen on EMB and yellow colonies on MSA indicate Escherichia coli and Staphylococcus aureus. The strains were isolated and used for additional studies.

\subsection{Antibiotic susceptibility test (ABST)}

Disc diffusion method (Kirby-Bauer disk diffusion susceptibility test protocol) is done to test the antibiotic susceptibility of pathogens on Muller-Hinton agar. The isolated $S$. aureus and E. coli were separately tested against five antibiotics. Disk diffusion method (Microbiology Systems, Becton Dickinson, USA, MD) as defined in the (NCCLS 2000) National Committee For Clinical Laboratory Standards were used to determine the results. The tested antibiotics and concentration ranges are methicillin $(5 \mathrm{mcg})$, ampicillin $(25 \mathrm{mcg})$, tetracycline $(30 \mathrm{mcg})$, amoxicillin $(30 \mathrm{mcg})$ and streptomycin $(30$ $\mathrm{mcg}$ ). The resistant pattern was identified by measuring the zone size and compared by the zone interpretation chart (as per CLSI).

\subsection{Collection and processing of plant}

C. amboinicus leaves (Figure 1, collected from Mannarkkad, Kerala, identified and authenticated with the number PIDA-3/2021 by Dr. Shamna, Deseeya Ayurvedic Factory, Calicut, Kerala) were washed with distilled water and dried in the shade at room temperature. The dried leaves were grounded to powders and stored in a sterile container for extraction.

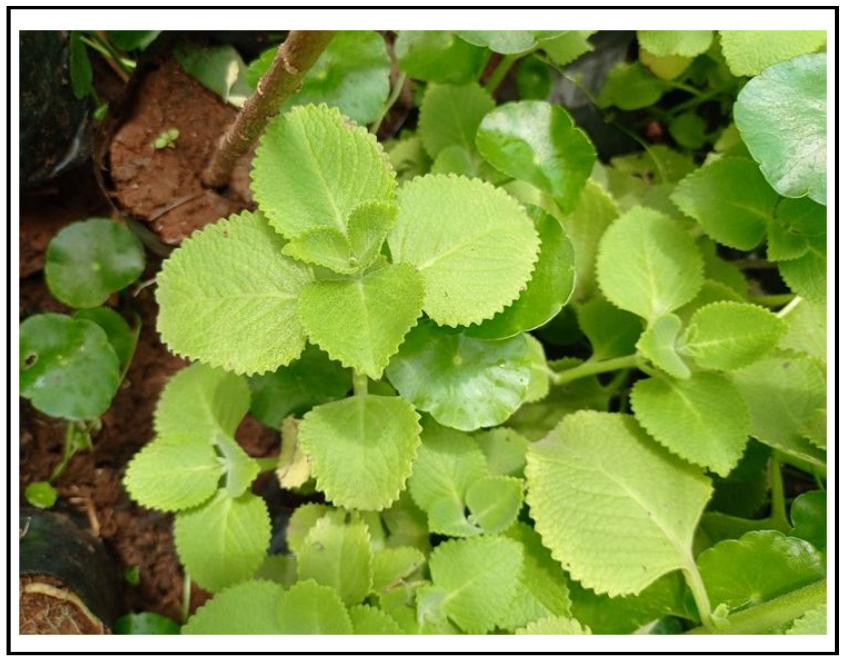

Figure 1: Coleus amboinicus used in the study.

\subsection{Extraction of bioactive compounds using Soxhlet apparatus}

Powders of $C$. amboinicus leaves were packed and positioned in a Soxhlet apparatus. Solvent solution of methanol is filled in the extractor, and the temperature of $60^{\circ} \mathrm{C}$ was set and left for $6 \mathrm{~h}$. The extracts were procured and the solvents were vaporised. The dried extracts were procured and kept in sterile containers.

\subsection{Antioxidant activity of the plant extracts}

\subsubsection{DPPH radical scavenging assay (Szerlauth et al., 2019)}

By utilising the stable radical 2,2-diphenyl-1-picrylhydrazyl (DPPH), as per the procedure described by Blois (1958), the antioxidant activity of the methanolic $C$. amboinicus extracts was 
assessed in terms of ability to donate hydrogen or scavenging radicals. Various concentrations $(100 \mu \mathrm{g}-1000 \mu \mathrm{g})$ of the extracts were taken and the total volume was adjusted to $100 \mu \mathrm{l}$ with methanol. About 3 $\mathrm{ml}$ of methanol solution of DPPH $(2.4 \mathrm{mg}$ in $100 \mathrm{ml})$ was mixed and allowed to rest for $30 \mathrm{~min}$ at $27^{\circ} \mathrm{C}$. The absorbance (OD values) was calculated at $517 \mathrm{~nm}$. Percentage radical scavenging activity of the sample was measured as follows:

$\%$ DPPH radical scavenging activity $=($ control OD-sample OD $/$ control OD) $\times 100$.

The assay was executed in triplicates and the outcomes were determined in mean $\pm \mathrm{SD}$.

\subsubsection{Ferric reducing antioxidant power (FRAP) assay (Naji $e$ al., 2020)}

The ferric reducing antioxidant power assay was utilised conferring to the method described by Strain and Benzie (1996) to evaluate the reducing ability of the plant extract. The FRAP reagent containing $2.5 \mathrm{ml}$ of $20 \mathrm{mMFeCl}_{3} \cdot 6 \mathrm{H}_{2} \mathrm{O}, 2.5 \mathrm{ml}$ of a $10 \mathrm{mMTPTZ}$ solution in 40 $\mathrm{mMHCl}$, and $25 \mathrm{ml}$ of $300 \mathrm{mM}$ acetate buffer ( $\mathrm{pH}$ 3.6) was prepared and kept at $37^{\circ} \mathrm{C} .3 \mathrm{ml}$ FRAP reagent was introduced with $60 \mu \mathrm{l}$ of the sample. The reaction mixture was set to incubation for $30 \mathrm{~min}$ at $37^{\circ} \mathrm{C}$ and the absorbance (OD values) was calculated at $610 \mathrm{~nm}$. $\mathrm{FeSO}_{4}$ at different concentrations were used for calibration.

\subsection{Antibacterial activity using well diffusion method}

Antibacterial efficacy of the plant extract was evaluated against the isolated clinical pathogens $S$. aureus and E. coli. Nutrient agar (nutrient agar composition for $100 \mathrm{ml}$ : sodium chloride: $0.5 \mathrm{~g}$, peptone: $0.5 \mathrm{~g}$; yeast extract: agar $1.5 \mathrm{~g}$; $0.5 \mathrm{~g}$, beef extract: $0.3 \mathrm{~g}$, total $\mathrm{pH}: 7.0$ \pm 0.2 ) was prepared and sterilized, and dispensed into plates.
Overnight cultures of test pathogens were used and the culture inoculum of each test organism was streaked with the sterile cotton swab by rotating the plate at a $60^{\circ}$ angle for every streaking. To bore wells on the agar surface, a $6 \mathrm{~mm}$ well borer was used. To each well, $100 \mu \mathrm{l}$ of the samples were added and the plates were kept in an incubator at $37^{\circ} \mathrm{C}$ for $48 \mathrm{~h}$. The antibacterial efficacy was identified based on the zone of inhibition around the wells in all the nutrient agar plates having test pathogens. The clear zones were observed and measured in millimetres $(\mathrm{mm})$

2.7 Evaluating minimum inhibitory concentration (MIC) of the plant extracts

To find out minimum inhibitory concentration (MIC), a slight modification of the dilution technique was performed. $1 \mathrm{ml}$ of plant extracts was diluted into various concentrations $(1.95 \mathrm{mg} / \mathrm{ml}, 3.9$ $\mathrm{mg} / \mathrm{ml}, 7.8 \mathrm{mg} / \mathrm{ml}, 15.6 \mathrm{mg} / \mathrm{ml}, 31.5 \mathrm{mg} / \mathrm{ml}, 62.5 \mathrm{mg} / \mathrm{ml}, 125 \mathrm{mg} / \mathrm{ml}$ and $250 \mathrm{mg} / \mathrm{ml}$, in $1 \mathrm{ml}$ of sterile nutrient broth in test tubes. A 100 $\mu \mathrm{l}$ of $E$. coli culture at $0.5 \mathrm{Mc}$ Farland standard (Eucast, 2003) was inoculated to the tubes. Correspondingly, this was repeated for $S$. aureus. The tubes were incubated at $37^{\circ} \mathrm{C}$ for $24 \mathrm{~h}$ and observed for growth or turbidity by using an unaided eye (CLSI, 2012).

\section{Results}

3.1 Antibiotic sensitivity test (Al Laham and Al Fadel, 2014)

The antibiotic sensitivity test is carried out to identify the resistant pattern of the isolated clinical pathogens. The sensitivity/resistance of the pathogens was tested against five broad-spectrum antibiotics. Figure 2 and Figure 3 show the resistance pattern of the pathogens against the antibiotics. The isolated clinical pathogen was resistant to four antibiotics (methicillin, ampicillin, tetracycline and amoxicillin) and intermediate to the streptomycin (Table 1).

Table 1: Antibiotic sensitivity test

\begin{tabular}{|c|c|c|c|c|}
\hline S. No & Pathogens & Antibiotics & Inhibitory zones ( $\mathrm{mm})$ & Interpretation \\
\hline 1 & Escherichia coli & $\begin{array}{l}\text { Methicillin } \\
\text { Ampicillin } \\
\text { Tetracycline } \\
\text { Amoxicillin } \\
\text { Streptomycin }\end{array}$ & $\begin{array}{l}- \\
- \\
- \\
- \\
12\end{array}$ & $\begin{array}{l}\mathrm{R} \\
\mathrm{R} \\
\mathrm{R} \\
\mathrm{R} \\
\mathrm{I}\end{array}$ \\
\hline 2 & Staphylococcus aureus & $\begin{array}{l}\text { Methicillin } \\
\text { Ampicillin } \\
\text { Tetracycline } \\
\text { Amoxicillin } \\
\text { Streptomycin }\end{array}$ & $\begin{array}{l}- \\
- \\
- \\
- \\
14\end{array}$ & $\begin{array}{l}\mathrm{R} \\
\mathrm{R} \\
\mathrm{R} \\
\mathrm{R} \\
\mathrm{I}\end{array}$ \\
\hline
\end{tabular}

*S-sensitive; I-intermediate; R-resistant

\subsection{Antioxidant activity of the plant extracts}

\subsubsection{DPPH radical scavenging activity}

DPPH radical scavenging activity of $C$. amboinicus extracts was evaluated using ascorbic acid as standard. Five concentrations of the plant extracts were used $(100 \mu \mathrm{g}, 250 \mu \mathrm{g}, 500 \mu \mathrm{g}, 750 \mu \mathrm{g}$ and 1000 $\mu \mathrm{g}) .100 \mu \mathrm{g}$ of plant extracts showed $13.68 \pm 2.35 \%$ of DPPH scavenging, $26.13 \pm 0.78 \%$ for $250 \mu \mathrm{g}, 43.77 \pm 1.54 \%$ for $500 \mu \mathrm{g}$, $65.21 \pm 0.88 \%$ for $750 \mu \mathrm{g}$ and $69.31 \pm 0.69 \%$ for $1000 \mu \mathrm{g}$. Similarly, ascorbic acid at showed $44.06 \pm 0.48 \%, 62.54 \pm 0.35 \%, 75.43 \pm$ $0.89 \%, 81.25 \pm 0.5 \%$ and $88.73 \pm 1.12 \%$ of DPPH scavenging for $100 \mu \mathrm{g}, 250 \mu \mathrm{g}, 500 \mu \mathrm{g}, 750 \mu \mathrm{g}$ and $1000 \mu \mathrm{g}$. Figure 4 shows the graphical representation of the DPPH radical scavenging activity of plant extract.

\subsubsection{Ferric reducing antioxidant power (FRAP)}

The ferric reducing antioxidant power of the plant extract was evaluated using 5 different concentrations. $100 \mu \mathrm{g}, 250 \mu \mathrm{g}, 500 \mu \mathrm{g}$, 
$750 \mu \mathrm{g}$ and $1000 \mu \mathrm{g}$ of plant extracts showed $26.13 \pm 0.97 \%, 58.29$ $\pm 0.41 \%, 64.82 \pm 0.58 \%, 70.36 \pm 1.27 \%$ and $78.35 \pm 0.32 \%$ of reducing power. Whereas, standard ascorbic acid showed $51.27 \pm$ $1.38 \%, 61.46 \pm 1.57 \%, 66.91 \pm 0.77 \%, 89.47 \pm 0.24 \%$ and $97.13 \pm$ $0.96 \%$ of reducing power. Figure 5 shows the graphical representation of reducing power of the plant extract.

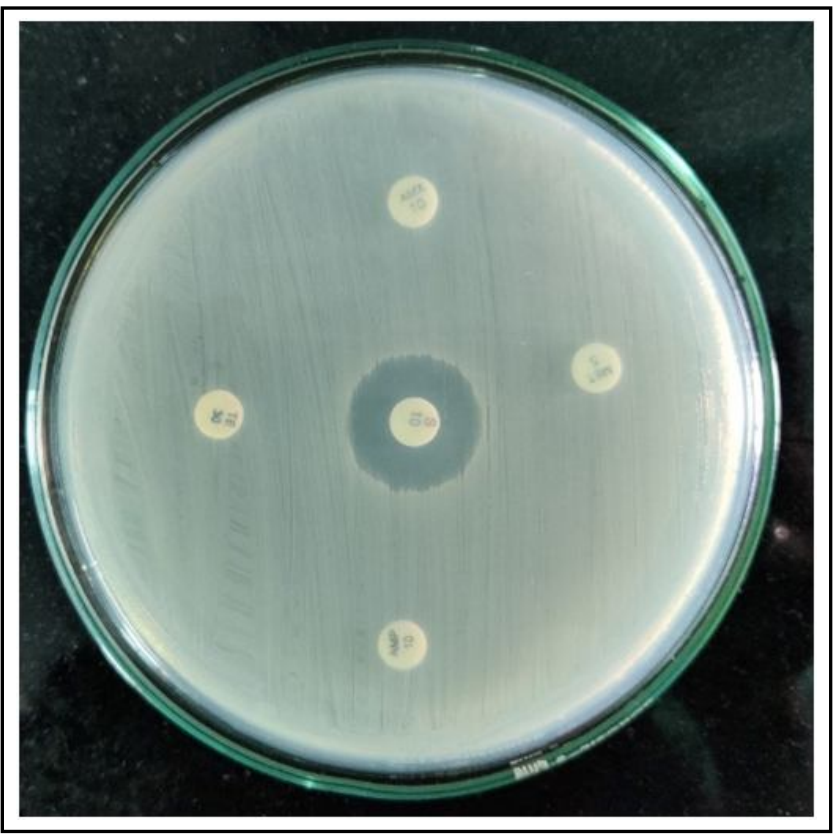

Figure 2: Antibiotic susceptibility of the Escherichia coli.

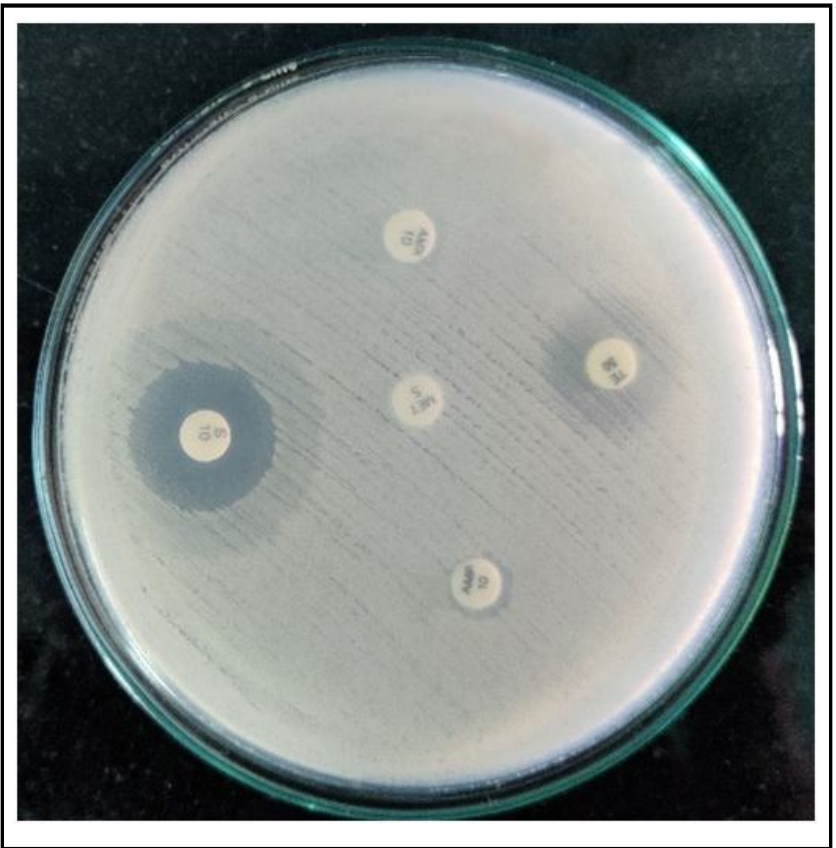

Figure 3: Antibiotic susceptibility of the Staphylococcus aureus.

\subsection{Antibacterial analysis}

Antibacterial activity of the $C$. amboinicus methanolic extracts were evaluated using the well diffusion method. Four concentrations, i.e., $125 \mathrm{mg} / \mathrm{ml}, 250 \mathrm{mg} / \mathrm{ml}, 500 \mathrm{mg} / \mathrm{ml}$ and $1000 \mathrm{mg} / \mathrm{ml}$ were used against the isolated multidrug resistant pathogens. $500 \mathrm{mg} / \mathrm{ml}$ and $1000 \mathrm{mg} /$ $\mathrm{ml}$ showed higher zones against both the test organisms. Figure 6 and Figure 7 show the antibacterial activity of the C. amboinicus extract against MDR E. coli and S. aureus using well diffusion method (Table 2 and Figure 8).

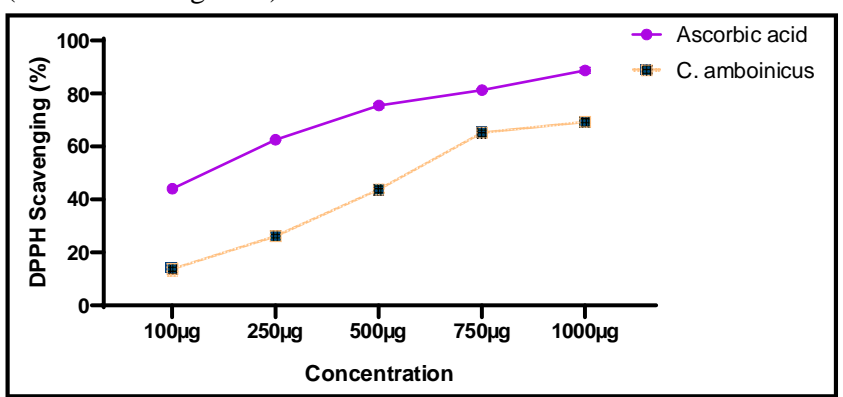

Figure 4: DPPH radical scavenging activity of $C$. amboinicus extracts.

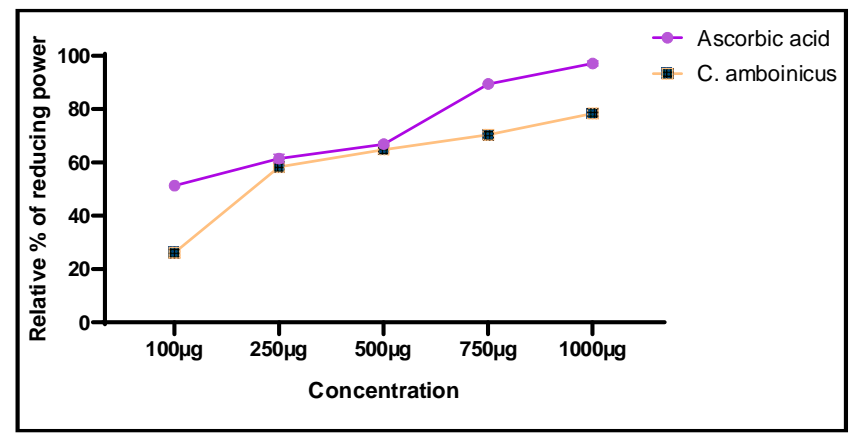

Figure 5: Ferric reducing antioxidant power of $C$. amboinicus extracts.

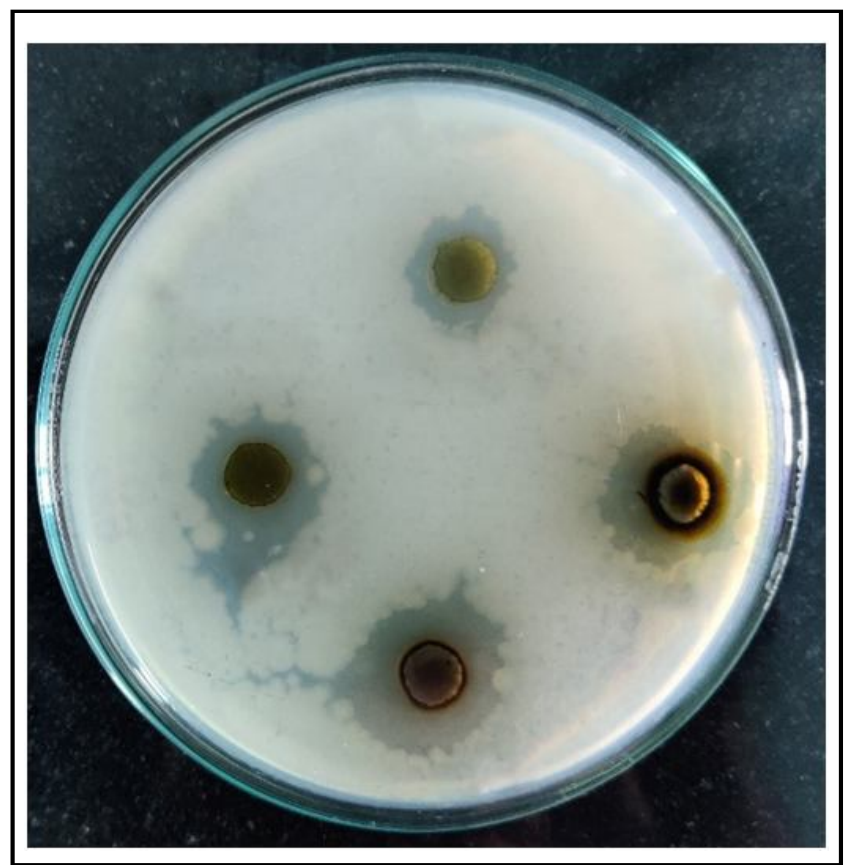

Figure 6: Antibacterial activity of $C$. amboinicus extracts against $E$. coli using well diffusion (extract concentration from top, clockwise: $0.125 \mathrm{~g}, 1 \mathrm{~g}, 0.5 \mathrm{~g}$ and $0.25 \mathrm{~g})$. 


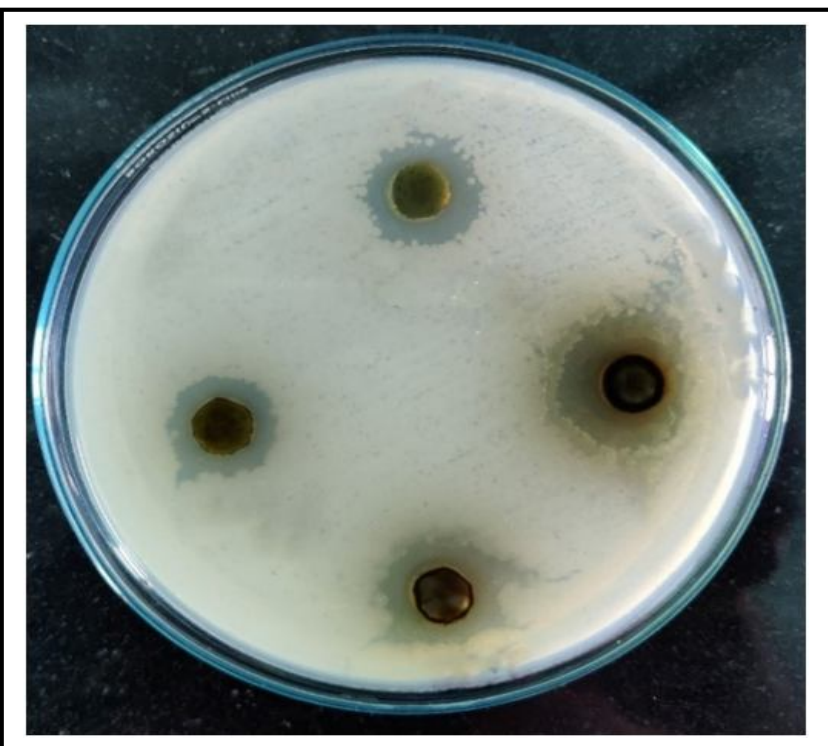

Figure 7: Antibacterial activity of $C$. amboinicus extracts against Staphylococcus aureus using well diffusion (extract concentration - from top, clockwise: $0.125 \mathrm{~g}, 1 \mathrm{~g}, 0.5$ $\mathrm{g}$ and $0.25 \mathrm{~g}$ ).

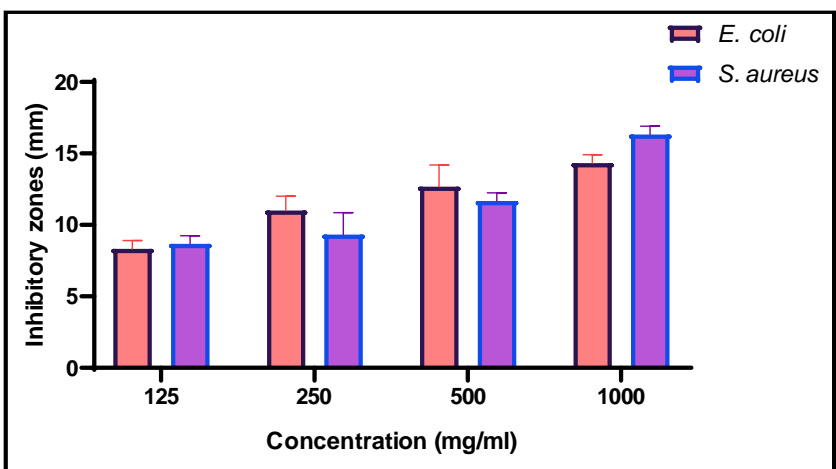

Figure 8: Antibacterial analysis of $C$. amboinicus extracts against MDR pathogens.

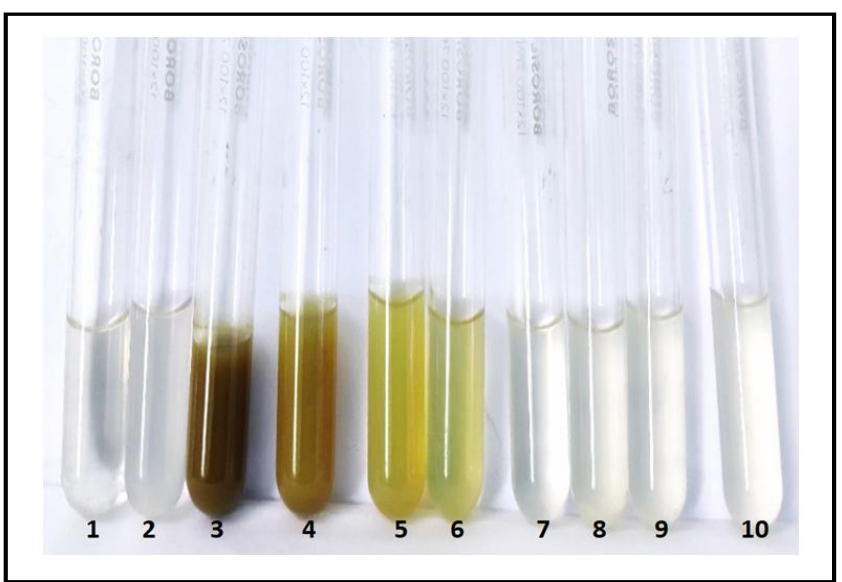

Figure 9: MIC evaluation C. amboinicus extracts against Escherichia coli (tubes from left to right: 1: positive control, 2: negative control, 3: $250 \mathrm{mg}, 4: 125 \mathrm{mg}$, 5: 62.5 mg, 6: $31.5 \mathrm{mg}, 7: 15.6 \mathrm{mg}, 8: 7.8 \mathrm{mg}, 9: 3.9 \mathrm{mg}$ and 10: $1.95 \mathrm{mg}$ ).
Table 2: Antibacterial activity of the C. amboinicus methanolic extracts using the well diffusion method

\begin{tabular}{|c|l|c|c|}
\hline S. No. & \multirow{2}{*}{ Concentration } & \multicolumn{2}{|c|}{ Inhibitory zones $(\mathbf{m m})$} \\
\cline { 3 - 4 } & & E. coli & S. aureus \\
\hline 1 & $125 \mathrm{mg} / \mathrm{ml}$ & $8.33 \pm 0.57$ & $8.66 \pm 0.57$ \\
2 & $250 \mathrm{mg} / \mathrm{ml}$ & $11 \pm 1$ & $9.33 \pm 1.52$ \\
3 & $500 \mathrm{mg} / \mathrm{ml}$ & $12.66 \pm 1.52$ & $11.66 \pm 0.57$ \\
4 & $1000 \mathrm{mg} / \mathrm{ml}$ & $14.33 \pm 0.57$ & $16.33 \pm 0.57$ \\
\hline
\end{tabular}

3.4 Minimum inhibitory concentration (MIC) analysis (Chikezie, 2017)

The minimum concentration of the plant extract that shows inhibition against the test pathogens were evaluated using the turbidity method. About 8 concentrations of the plant extracts were used. The concentration showing no growth of the pathogen was identified by comparing with the positive control. Figure 9 shows the MIC determination against $E$. coli and Figure 10 shows the MIC determination against $S$. aureus. From the analysis, MIC of $E$. coli and $S$. aureus was found to be $15.6 \mathrm{mg}$ and $7.8 \mathrm{mg}$, respectively.

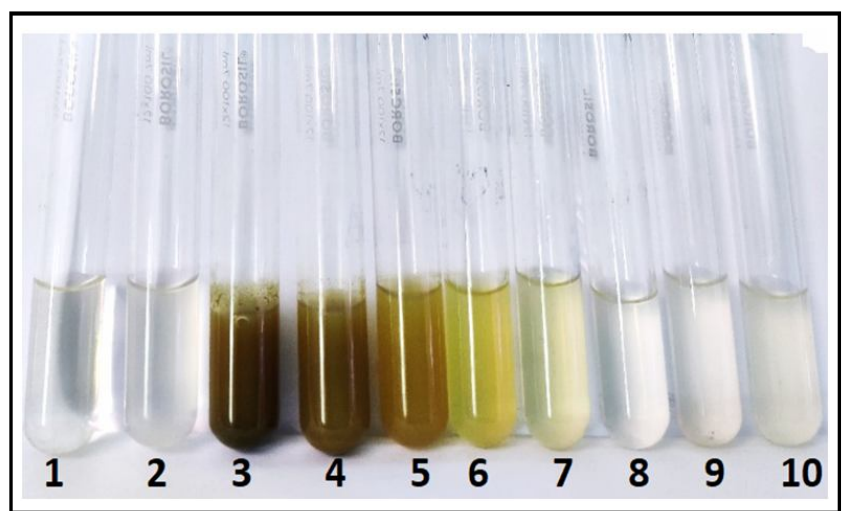

Figure 10: MIC evaluation C. amboinicus extracts against Staphylococcus aureus (tubes from left to right: 1: positive control, 2: negative control, 3: $250 \mathrm{mg}$, 4: $125 \mathrm{mg}, 5: 62.5 \mathrm{mg}, 6: 31.5 \mathrm{mg}, 7: 15.6 \mathrm{mg}, 8: 7.8 \mathrm{mg}$, 9: $3.9 \mathrm{mg}$ and $10: 1.95 \mathrm{mg}$ ).

\section{Discussion}

World health organisation (WHO) has announced antimicrobial resistance and a global crisis. Antimicrobial resistance is an emerging issue following the COVID-19. Development of novel antibiotics has become necessary for treatment of MDR infections. Plants serves as a potential source for development of novel drugs and herbal based drugs are often safe. Therefore, the present study focuses on evaluating the anti-MDR bacterial activity of the $C$. amboinicus.

C. amboinicus is native to Southern and Eastern Africa, ranging from South Africa (KwaZulu-Natal) and Eswatini to Angola and Mozambique, and north to Kenya, Tanzania, and India, though it is largely grown and naturalised elsewhere in the tropics, where it can be found in coastal or bushwoodland, on rocky slopes and loamy or sandy flats at low elevations. C. amboinicus is a medicinal plant that has been used for centuries to cure a variety of ailments including throat infections, cough and fever, diarrhoea, nasal congestion, and digestive issues. Endophytic fungi that produce antibacterial 
compounds were found in the plant. It is commonly used to treat colds and also it aids in the prevention of foul breath.

C. amboinicus leaves were collected and dried. Bioactive compounds were extracted using methnol as solvent. Leaf extracts showed significant inhibitory zones against multidrug resistant bacterial pathogens. Menéndez and Pavón (1999) found that an ethanolic extract of $C$. amboinicus has bacteriolytic activity against $S$. aureus and intestinal infections. The antibacterial action of $C$. amboinicu sessential oil, as reported by Judith et al. (2009) is most likely owing to the presence of carvacrol, which accounts for $65.2 \%$ of the oil and is well recognised as an antibacterial and insecticidal. Only ethanolic extracts demonstrated antibacterial action against all strains, whereas aqueous extracts showed no activity at all. According to Nivya et al., (2014) ethanol extracts from the leaves of $C$. amboinicus showed antibacterial efficacy against Bacillus cereus, Bacillus subtilis, $S$. aureus, Shigella flexneri and Salmonella paratyphi. A. These findings well correlates with the present study.

Furthermore, essential oil derived from the leaf of $C$. amboinicus was found to have antifungal action against two fungus species, Candida albicans and Aspergillus niger (Anjali et al., 2014). The highest zone of inhibition was identified against Candida albicans. Vizoso et al. (1999) showed dose-dependent cytotoxic and genotoxic effects against Aspergillus nidulans, indicating that the essential oil of $C$. amboinicus has antifungal potential. Farida et al. (2020) evaluated the cytotoxicity of $C$. amboinicus against colon cancer, finding that the extract had substantial anticolon cancer action against WiDr cells when compared to 5-flurouracil, a conventional medication. According to Puji et al. (2021), C. amboinicus demonstra-ted modest cytotoxicity against T47D cells and was not selective towards normal cells and so has the potential to be used as a lead chemical therapeutic agents.

\section{Conclusion}

Anti-multidrug resistant bacterial activity of $C$. amboinicus against multidrug resistant Escherichia coli and Staphylococcus aureus was investigated in the present study. The clinical pathogens were collected and antibiotic susceptibility test was performed using standard antibiotics to evaluate the resistant pattern of the pathogens. Bioactive compounds of the $C$. amboinicus leaves were extracted using methanol as solvent. The antibacterial activity and minimum inhibitory concentration (MIC) of the leaf extract against isolated MDR pathogens was investigated. From the analysis, bioactive compounds from $C$. amboinicus showed evident antibacterial activity against MDR pathogens. Apart from the antibacterial analysis other biological properties of the plant extract, i.e., antioxidant activity was performed. The plant extract showed significant antioxidant values on DPPH radical scavenging and reducing power. Further studies are required to purify the bioactive compounds responsible for the antibacterial action and such compounds can be used for novel antibiotics for treatment of MDR infections.

\section{Acknowledgements}

The authors are grateful to the Deanship of Scientific Research, Prince Sattam bin Abdulaziz University, Al-Kharj, Saudi Arabia for its support for this research work.

\section{Conflict of interest}

The authors declare no conflicts of interest relevant to this article.

\section{References}

Al Laham, S.A. and Al Fadel, F.M. (2014). Antibacterial activity of various plants extracts against antibiotic-resistant aeromonas hydrophila. Jundishapur J. Microbiol. 7. https://doi.org/10.5812/jjm.11370.

Anjali M.; Elza J.; Nayomi J.; Ajitha A. R. andShanti, A.A.(2014). Phytochemical screening and evaluation of the antimicrobial potential of Coleus amboinicus. Volume, 3(2):2811-2826.

Chikezie, I.O. (2017). Determination of minimum inhibitory concentration (MIC) and minimum bactericidal concentration (MBC) using a novel dilution tube method. African J. Microbiol. Res., 11:977-980. https:/ /doi.org/10.5897/ajmr2017.8545.

Elbehiry, A.; Marzouk, E.; Moussa, I.M.; Alenzi, A.; Al-Maary, K.S.; Mubarak, A.S.; Alshammari, H.D.; Al-Sarar, D.; Alsubki, R.A.; Hemeg, H.A.; Kabli, S.A. and Attala, O.A. (2021). Multidrug-resistant Escherichia coli in Raw Milk: molecular characterization and the potential impact of camel's urine as an antibacterial agent. Saudi J. Biol. Sci., 28:2091-2097. https://doi.org/10.1016/j.sjbs.2021.01.018.

Gayathiri, M.; Thiribhuvanamala, G.; Krishnamoorthy, A.S.; Haripriya, S.; Akshaya, S.B. and Arumukapravin, I. (2021). Characterization of antimicrobial metabolites from medicinal mushrooms against Mango anthracnose pathogen Colletotrichum gloeosporioides (Penz.) Sacc. Ann. Phytomed., 10(1):185-194. http://dx.doi.org/10.21276/ ap.2021.10.1.19.

Judith, V.; Luis B. R.; Tulia, D. and Alfredo, U. (2009). Chemical composition and antibacterial activity of the essential oil of Coleus amboinicus Lour., against enteric pathogens. Journal of Essential Oil Bearing Plants, 12:453-461.

Elbossaty, W.F. (2017). Antibiotic drugs and multidrug resistance bacteria. Cit. Elbossaty WF. Int. J. Pub. Heal. Safe, 2:2-4.

Farida, L.; Dedi, F.; Nancy Dewi, Y.; Rizal, M.D. and Fitriya N.D. (2020). Methanol extract of Coleus amboinicus (Lour) exhibited antiproliferative activity and induced programmed cell deathin colon cancer cell Wi Dr. International Journal of Food Science, Volume 2020, Article ID 9068326, 12 page.

Menéndez, R. and Pavón, V. (1999). Plectranthus amboinicus (Lour.) Spreng. Rev. Cubana Plant. Med., 3:110-115.

Naji, K.M.; Thamer, F.H.; Numan, A.A.; Dauqan, E.M.; Alshaibi, Y.M. and D'souza, M.R. (2020). Ferric-bipyridine assay: A novel spectrophotometric method for measurement of antioxidant capacity. Heliyon 6. https:/ /doi.org/10.1016/j.heliyon.2020.e03162.

Nivya, M.P.; Anjali, M.; Elza, J.; Nayomi, J.; Ajitha, A.R. and Shanti, A.A. (2014). Phytochemical screening and evaluation of the antimicrobial potential of Coleus amboinicus. Volume 3(2):2811-2826.

Panjla, A.; Kaul, G.;Shukla, M.; Tripathi, S.; Nair, N.N.; Chopra, S. and Verma, S. (2019). A novel molecular scaffold resensitises multidrug-resistant S. aureus to fluoroquinolones. Chem. Commun., 55:8599-8602. https:/ /doi.org/10.1039/c9cc03001h.

Puji, A.; Rollando;Pratoko, D.; Wahyuono, Subagus and Nurrochmad, A. (2021). Antimicrobial and cytotoxic activities of a compound produced by an endophytic fungus isolated from the leaves of Coleus amboinicus Lour. Journal of Pharmaceutical Research International, 13:26322644.

Read, A.F. (2020). Superbugs: The race to stop an epidemic. Emerg. Infect. Dis., 26. https://doi.org/10.3201/eid2605.191717.

Rolain, J.M.; Abat, C.; Jimeno, M.T.; Fournier, P.E. and Raoult, D. (2016). Do we need new antibiotics? Clin. Microbiol. Infect. https://doi.org/ 10.1016/j.cmi.2016.03.012. 
Samanjit, K. and Sneha Hariharan, S.D. (2020). Superbugs: The powerful warriors. Int. J. Pharm. Sci. Res., 11:1506-1526. https://doi.org/ 10.13040/IJPSR.0975-8232.11(4):1506-26

SaravanaKumari, P.; Ranjitha, R. and Vidhya, N. (2020). Revitalizing property of banana peel extracts by antioxidant activity and antibacterial activity against acne causing Staphylococcus epidermidis. Ann. Phytomed., 9(2):215-222. http://dx.doi.org/10.21276/ap.2020. 9.2.19

Szerlauth, A.; Muráth, S.; Viski, S. and Szilagyi, I. (2019). Radical scavenging activity of plant extracts from improved processing. Heliyon 5 . https://doi.org/10.1016/j.heliyon.2019.e02763

Umamaheswari, D.; Muthuraja, R.; Kumar, M. and Venkateswarlu, B.S. (2021). Standardisation of herbal drugs. A overview. Int. J. Pharm. Sci.
Rev. Res., 68. https://doi.org/10.47583/ijpsrr.2021.v68i01. 033 .

Vidya, D.S. (2021). Identification of antibacterial phytochemicals in Terminalia arjuna and Andrographis paniculata for the treatment of multidrug resistant (MDR) bacterial pathogens: An in silico analysis. Ann. Phytomed., 10(1):141-159. http://dx.doi.org/10.21276/ ap.2021.10.1.15

Vizoso, A.; Ramos, A.; Edreira, A.; Edreira, A.; Bentancourt, J. and Décalo, M. (1999). Plectranthus amboinicus (Lour.) Spreng (Orégano Francés). Estudio toxicogenético de un extracto fluido y del aceite esencial. Rev. Cubana Plant. Med., 4:68-73.

Wieczorek, K. and Osek, J. (2011). Antimicrobial resistance of selected microorganisms isolated in the countries of European Union. Zycie Weter, 86:118-122. 